\title{
HUBUNGAN ANTARA PENGETAHUAN TENTANG PENGELOLAAN SAMPAH DAN PERILAKU BERTANGGUNG JAWAB SISWA DI SMAN 34 JAKARTA
}

\author{
Suhardjo $^{1}$, Nindirawati Citra Dewi ${ }^{2}$ \\ Pendidikan Geografi Fakultas Ilmu Sosial \\ Universitas Negeri Jakarta
}

Email:mr_suhardjo@yahoo.com

\begin{abstract}
This study aims to determine how strong is the relationship between understanding about waste management and responsible behavior of students in 34 high schools in Jakarta. This research was conducted in March - July 2017. The method used is a quantitative method with a field survey approach. The population in this study were all students who attended 34 high schools. The total population was 25 members registered as KIR members at 34 SMAN Jakarta. Sampling is done by the whole sampling technique. In the sample in this study, I chose to use students who actively participated in the Youth Scientific Work (KIR) organization. Data collection techniques using a closed questionnaire. Data analysis techniques using correlation analysis. It is testing the research instrument in the form of a validity test and a reliability test using SPSS version 16.0 and testing the validity of the correlation item analysis $>r_{\text {table. }}$. Measurement of the validity of knowledge variables based on the Pearson correlation value $>r$ table of the 25 items that had a Pearson correlation score between -0,089-0,915 dan $r$ table 0,3809 so that 3 things are invalid and deleted, so in this study there are 22 items. It is testing the validity of the correlation item analysis $>r$ table. Measurement of the validity of behavior variables based on the Pearson correlation value $>r_{\text {table }}$ from 25 Item items have a Pearson correlation score between 0,2150,896 and $r$ table 0,3809 so that 3 things are invalid and deleted, so in this study there are 22 items. Reliability measurements are based on Cronbach's Alpha values. Score reliability knowledge of 0.795 and 874 behavior, meaning that the cost is categorized as reliable. Based on the results of the study, note that the relationship between knowledge of waste management and responsible behavior results is not significant. It is seen from the results of the correlation test. It is known that the result is 0.928 which is smaller than 0.050. It can be concluded that the relationship between knowledge of waste management and responsible behavior has a shallow relationship
\end{abstract}

Keywords: Knowledge, Waste Management, Behavior, Responsible students

\begin{abstract}
Abstrak
Penelitian ini bertujuan untuk mengetahui seberapa kuat hubungan antara pemahaman tentang pengolahan sampah dengan perilaku bertanggung jawab siswa di sekolah menengah atas 34 Jakarta. Penelitian ini dilaksanakan pada bulan Maret - Juli 2017. Metode yang digunakan adalah metode kuantitatif dengan pendekatan survey lapangan. Populasi dalam penelitian ini adalah seluruh siswa yang bersekolah di SMA Negeri 34. Jumlah total populasi adalah 25 anggota yang terdaftar sebagai anggota KIR di SMAN 34 Jakarta. Pengambilan sampel dilakukan dengan teknik total sampling. Sampel dalam penelitian ini saya memilih untuk menggunakan siswa yang aktif mengikuti organisasi Karya Ilmiah Remaja (KIR). Teknik pengambilan data menggunakan kuesioner tertutup. Teknik analisis data menggunakan analisis korelasi. Pengujian instrumen penelitian berupa uji validitas dan uji reliabilitas dengan menggunakan SPSS versi 16.0. Pengujian validitas dengan analisis correlation item $>\mathrm{r}$ tabel. Pengukuran validitas variable pengetahuan berdasarkan nilai pearson correlation $>\mathrm{r}$ tabel dari 25 item soal memiliki skor pearson correlation antara $-0,089-0,915$ dan $\mathrm{r}_{\text {tabel }} 0,3809$ sehingga terdapat 3 item soal tidak valid dan dihapus, sehingga dalam penelitian ini terdapat 22 item soal. Pengujian validitas dengan analisis correlation item $>r_{\text {tabel. }}$. Pengukuran validitas variable perilaku berdasarkan nilai pearson correlation $>r$
\end{abstract}


tabel dari 25 item soal memiliki skor pearson correlation antara 0,215-0,896 dann $\mathrm{r}$ tabel 0,3809 sehingga terdapat 3 item soal tidak valid dan dihapus, sehingga dalam penelitian ini terdapat 22 item soal. Pengukuran reliabilitas berdasarkan nilai Cronbach's Alpha. Nilai reliabilitas pengetahuan sebesar 0,795 dan perilaku 874, artinya nilai tersebut dikategorikan reliabel. Berdasarkan hasil penelitian diketahui bahwa hubungan antara pengetahuan pengelolaan sampah dan perilaku bertanggung jawab hasilnya tidak signifikan. Hal ini dilihat dari hasil uji korelasi diketahui hailnya adalah 0,928 yang merupakan lebih kecil dari 0,050. Bisa disimpulkan bahwa hubungan pengetahuan pengelolaan sampah dan perilaku bertanggung jawab memiliki hubungan sangat rendah.

Kata Kunci : Pengetahuan, Pengelolaan Sampah, Perilaku, Bertanggung jawab siswa

\section{PENDAHULUAN}

Sekolah sebagai salah satu aspek penting dalam pembinaan dan pengajaran tentang lingkungan hidup yang sehat dan baik. Oleh sebab itu guru maupun lingkungan masyarakat di sekolah juga memiliki peran dalam memberikan contoh yang baik dalam menjaga lingkungan. Salah satunya adalah dengan dapat mengikutsertakan siswa dalam kegiatan yang dapat mengurangi sampah di kehidupan sehariharinya dimulai dari aspek yang paling kecil yaitu dari lingkungan sekolahnya sendiri. Dari hal tersebut siswa dapat diketahui kepeduliannya terhadap kepedulian lingkungan yang ada di sekolahnya.

Umumnya di sekolah memiliki pengolahan sampah yang berbeda-beda sesuai dengan ketentuan sekolah masingmasing tetapi dalam pengolahan sampah organik biasanya mereka mengubahnya menjadi pupuk organik yang digunakan untuk tanaman-tanaman yang ditanam di green house sekolah. Sedangkan untuk perawatannya biasanya dilakukan oleh pegawai khusus yang telah ditunjuk sekolah ataupun juga dilakukan oleh siswa maupun siswi yang mengikuti organisasi ekskul KIR (Karya Ilmiah Remaja) yang dalam pengolahan maupun perawatan tanaman. Di lokasi green house para siswa dan siswi biasanya akan didampingi oleh guru pembina ekskul maupun petugas yang telah ditunjuk oleh sekolah. Namun biasanya sampah yang dapat diolah oleh pihak sekolah umumnya hanya sebatas pada sampah dari tanaman yang telah mati ataupun rontok yang berada biasanya disekitar lingkungan sekolah. Dan sisa dari sampah-sampah yang lain seperti dari sisa makanan, bungkusbungkus jajanan seperti snack maupun bungkus dari makanan yang didapat dari kantin seperti mika plastik ataupun plastik yang lain. Hanya akan dibiarkan tertumpuk ditempat sampah saja dan akhirnya harus diangkut ke tempat 
pembuangan sampah sementara yang berada di lokasi terdekat dari sekolah tersebut. Hal tersebut tentunya jika dilihat dari jangka pendek bukanlah menjadi hal yang penting untuk diselesaikan. Tetapi jika hal tersebut terus terjadi sepanjang hari dan terjadi selama bertahun-tahun tentunya akan menyebabkan sampah yang sangat banyak dan sulit untuk diuraikan kembali. Akibatnya sampah yang dihasilkan bukan tidak mungkin akan semakin meningkat dari waktu ke waktu jika tidak diselesaikan dengan cara yang cermat. Berdasarkan uraian fakta di atas, maka permasalahan penelitian ini adalah adakah hubungan antara pengetahuan pengolahan sampah dengan perilaku bertanggung jawab siswa khususnya di SMA Negeri 34 Jakarta.

Pengetahuan adalah sesuatu yang dikemukakan seseorang yang merupakan hasil dari tahu. Hal ini dapat terjadi setelah individu melakukan penginderaan terhadap suatu obyek tertentu. Penginderaan terjadi melalui panca indra manusia, yakni indra penglihatan, pendengaran, penciuman, rasa dan raba, dimana sebagian penginderaan manusia diperoleh melalui mata dan telinga. Bertrand Russel (Jujun
Suriasumantri. 1980) mengatakan bahwa hakekat pengetahuan adalah bersifat derajat. Derajat tertinggi ditemukan dalam fakta persepsi, dan dalam keyakinan yang diberikan oleh argumentasi yang sangat sederhana. Derajat yang paling tertinggi berikutnya adalah dalam ingatan yang terang. Bila sejumlah kepercayaan adalah masingmasing sampai tahap tertentu dapat dipercaya, mereka akan lebih bisa dipercaya lagi bila mereka ternyata ditemukan bersifat koheren dalam keseluruhan yang logis.

Adapun dalam tulisan Tatang (Tatang. 2012) sumber pengetahuan tidak hanya berakar dari akal pikiran manusia dengan kemampuan kognitifnya, tetapi karena manusia dilengkapi dengan kecerdasan memahami realitas dan menantang manusia untuk menduga-duga dalam memikirkan dan memahaminya setiap kejadian yang mungkin terjadi secara fenomenologis. Seperti juga dikemukakan oleh Bruner, salah seorang tokoh teori konstruktif, bahwa belajar adalah sebuah proses aktif di mana peserta didik menyusun dan membangun ide-ide atau konsep berdasarkan struktur pengetahuan yang dimilikinya (Mark K. 
Smith. 2004). Dengan demikian, menurut teori konstruktif proses pembelajaran yang bermakna harus bermula dari pengetahuan yang telah dimiliki peserta didik.

Teori lain yang mendukung adalah teori belajar behavior. Menurut teori behavior, lingkungan merupakan salah satu unsur yang menyediakan stimulus yang menyebabkan tanggapan individu berkembang. Atas dasar itu teori behavior menyatakan bahwa suatu perilaku itu dibentuk oleh lingkungan. Perubahan perilaku yang terjadi pada peserta didik merupakan hasil belajar. Dengan demikian, perubahan perilaku juga merupakan hasil belajar seseorang terhadap lingkungannya. Dari keseluruhan teori belajar yang diungkapkan di atas, dapat disimpulkan bahwa desain interaksi pembelajaran antara peserta didik dengan lingkungan dapat diharapkan cukup efektif dalam pembentukan pemahaman dan perilakunya terhadap lingkungan.

Dalam penelitian ini menyajikan pokok-pokok bahasan tentang kehidupan manusia dengan alam lingkungan sekitar, sehingga dapat membantu proses pendidikan lingkungan hidup seperti pencemaran, abrasi, kelaparan, pengangguran, penggunaan lahan, dan lain sebagainya. Proses pembelajaran terkait tujuan penelitian yang materi dan obyeknya digali dari kehidupan dengan alam lingkungan sekitar, dapat menanamkan nilai-nilai keindahan, kemanusiaan, dan bahkan juga nilai-nilai Ketuhanan, sehingga membina sikap mental yang baik terhadap pemeliharaan alam lingkungan ciptaan Tuhan. Bagi bangsa Indonesia, hal ini erat hubungannya dengan ketakwaan kepada Tuhan Yang Maha Esa yang mencerminkan sila Ketuhanan.

Dengan memperhatikan fungsi tersebut, khususnya tanggung jawab terhadap lingkungan, maka proses pembelajaran yang dilakukan dapat menumbuhkan perilaku yang bertanggung jawab terhadap lingkungan. Dalam pelaksanaan, perilaku bertanggung jawab terhadap lingkungan tidak begitu saja tumbuh dalam masyarakat, melainkan harus ditanamkan melalui beberapa cara yang salah satu di antaranya adalah melalui pembelajaran dalam setiap moment uji coba materi berdasarkan objeknya. Menanamkan perilaku yang bertanggung jawab terhadap lingkungan bukanlah hal yang mudah, tetapi dengan melibatkan 
masyarakat sebagai bagian dari lingkungan dan berperan dalam ekosistem, diharapkan tumbuh kesadaran terhadap lingkungan, sehingga ia dapat menyadari setiap perbuatannya terhadap lingkungan bisa meminimalkan kerusakan lingkungan dan pada gilirannya dapat meningkatkan kualitas lingkungan pada masa kini dan masa depan.

\section{METODOLOGI PENELITIAN}

Penelitian ini bertujuan untuk mengetahui seberapa kuat hubungan antara pemahaman tentang pengolahan sampah dengan perilaku bertanggung jawab siswa di sekolah menengah atas 34 Jakarta. Penelitian ini dilaksanakan pada bulan Maret - Juli 2017. Metode yang digunakan adalah metode kuantitatif dengan pendekatan survey lapangan. Populasi dalam penelitian ini adalah seluruh siswa yang bersekolah di SMA Negeri 34. Jumlah total populasi adalah 25 anggota yang terdaftar sebagai anggota KIR di SMAN 34 Jakarta. Pengambilan sampel dilakukan dengan teknik total sampling. Sampel dalam penelitian ini saya memilih untuk menggunakan siswa yang aktif mengikuti organisasi Karya Ilmiah Remaja (KIR). Teknik pengambilan data menggunakan kuesioner tertutup. Teknik analisis data menggunakan analisis korelasi.

\section{HASIL DAN PEMBAHASAN}

a. Pengetahuan tentang pengelolaan sampah

1) Indikator Pengertian Sampah; ratarata responden telah paham dan mengetahui tentang apa itu sampah secara umum yang dapat dilihat sehari-hari.

2) Indikator Penggolongan Sampah; rata-rata responden telah paham dan mengetahui tentang penggolongan sampah seperti apa, dan bagaimana pemisahan-nya berdasarkan lokasi, asal maupun karakteristik dari sampah itu sendiri.

3) Indikator Penanganan Sampah; rata-rata responden telah paham dan mengetahui tentang penanganan sampah yang baik dan benar, serta bagaimana penanganan sampah yang baik untuk kehidupan sehari-hari.

4) Indikator Pemanfaatan Sampah; rata-rata responden telah sangat paham dan mengetahui tentang bagaimana pemanfaatan sampah yang baik yang tidak hanya dapat 
menjaga lingkungan tetapi dapat juga memberikan keuntungan dari segi ekonomis.

b. Perilaku bertanggung jawab

Data perilaku bertanggung jawab diperoleh melalui pengisian instrumen berupa kuesioner sebanyak 25 pertanyaan yang diisi oleh 25 responden. Item keseluruhan dinyatakan valid. Indikator perilaku bertanggung jawab meliputi, empati terhadap lingkungan, pengidentifikasian isu lingkungan, kesadaran untuk menjaga kualitas lingkungan, dan keterlibatan dalam mencapai hasil yang diinginkan. Perilaku bertanggung jawab dalam aspek empati terhadap lingkungan adalah mengetahui bagaimana perilaku para responden terhadap kepeduliannya terhadap lingkungan sekitar. Perilaku bertanggung jawab dalam aspek pengidentifikasian isu lingkungan adalah mengetahui info terkini terkait berita atau isu-isu yang berkaitan dengan lingkungan saat ini yang ada disekitar kita. Perilaku bertanggung jawab dalam aspek kesadaran untuk menjaga kualitas lingkungan adalah mengetahui pemahaman atau kesadaran responden terhadap cara atau upaya yang tepat untuk menjaga kualitas atau keadaan lingkungan sekitarnya. Perilaku bertanggung jawab dalam aspek keterlibatan dalam mencapai hasil yang diinginkan adalah mengetahui sejauh mana keterlibatan atau kontribusi responden terhadap upaya menjaga lingkungan yang ada disekitarnya.

Setiap pertanyaan yang ditanyakan memiliki 5 (lima) alternatif dalam menjawab, yaitu jawaban 5 = sangat setuju, $4=$ setuju, 3 = ragu-ragu, 2 = tidak setuju dan 1 = sangat tidak setuju. Data yang telah didapatkan kemudian dideskripsikan. Hasil dari deskripsi data akan disajikan dengan menggunakan tabel jawaban responden menunjukkan bahwa pengetahuan pengolahan sampah meliki skor terendah adalah $25(1 \mathrm{x}$ 25) dan skor tertinggi adalah 125 ( $5 \times 25$ ) dari tiap pertanyaan yang dijawab, jika dilihat dari persentase maka akan dimulai dari 0\% sampai 100\%. Dari hasil kuesioner yang disebar diperoleh skor terndah adalah 73 dan skor tertinggi adalah 
Jurnal Parameter Volume 31 No. 1

DOI : doi.org/10.21009/parameter.311.05

P-ISSN : 0216-261X E-ISSN : 2620-9519

123, sedangkan skor rata-rata sebesar 97,88 .

1) Indikator Empati terhadap lingkungan

a) Rata-rata responden menyetujui perilaku empati yang ada di lingkungan sekitarnya dengan baik, ini dapat dilihat banyaknya responden yang menjawab setuju dengan pernyataan tentang perilaku empati terhadap lingkungan yang ada.

b) Rata-rata responden mengetahui isu-isu lingkungan yang ada disekitar sehari-hari dengan baik, ini dapat dilihat banyaknya responden yang menjawab setuju dengan pernyataan tentang isu-isu lingkungan berkaitan tentang pengolahan sampah yang ada.

2) Indikator Kesadaran untuk menjaga kualitas lingkungan

Rata-rata responden menyetujui pernyataan tentang kesadaran untuk menjaga lingkungan sekitarnya dengan baik, ini dapat dilihat banyaknya responden yang menjawab setuju dengan pernyataan tentang kesadaran untuk menjaga kualitas lingkungan yang ada disekitarnya.

3) Indikator Keterlibatan dalam mencapai hasil yang diinginkan Rata-rata responden telah ikut terlibat dalam upaya mencapai hasil yang diinginkan dari lingkungan sekitarnya dengan baik, ini dapat dilihat banyaknya responden yang setuju dengan pernyataan tentang perilaku dalam keterlibatan mencapai hasil yang diinginkan dalam upaya untuk menjaga lingkungan dan perilaku bertanggung jawab dari tugas sebagai siswa KIR yang ada.

Berdasarkan hasil analisis, diketahui bahwa dari total 25 responden yang diteliti sebagian besar berada di tingkat pendidikan kelas 10 sebanyak 16 responden dengan persentase dari keseluruhan adalah 64\%, dan untuk jenis kelamin yang diteliti adalah siswa perempuan sebanyak 16 responden dengan persentase $64 \%$ dari total keseluruhan. (1) Partisipasi responden dilihat dari indikator pengertian sampah memiliki rata-rata persentase yang baik yaitu terdapat $60 \%$ responden yang 
menjawab benar dalam indikator ini. Hal itu menandakan bahwa pengetahuan mereka terhadap sampah secara umum cukup baik. (2) Partisipasi responden dilihat dari indikator penggolongan sampah memiliki rata-rata persentase yang baik yaitu terdapat $76 \%$ responden yang menjawab benar dalam indikator ini. Hal itu menandakan bahwa pengetahuan responden secara rata-rata telah cukup baik dalam mengetahui penggolongan sampah baik dari bentuk, sifat dan asalnya. (3) Partisipasi responden dilihat dari indikator penanganan sampah memiliki rata-rata persentase yang baik yaitu terdapat $61 \%$ responden yang menjawab benar dalam indikator ini. Hal itu menandakan bahwa pengetahuan mereka terhadap penanganan masih cukup baik, persentase paling rendah ada di bagian mengenai prinsip 3R. (4) Partisipasi responden dilihat dari indikator pemanfaatan sampah memiliki rata-rata persentase yang baik yaitu terdapat $62 \%$ responden yang menjawab benar dalam indikator ini. Hal itu menandakan bahwa pengetahuan mereka terhadap pemanfaatan sampah yag ada disekitar mereka cukup baik, persentase paling rendah ada dibagian materi tentang pengolahan limbah menggunakan teknik dan alat khusus dimana hal tersebut jarang mereka lakukan atau liat seharihari.

Sedangkan jika dilihat dari aspek yang satu lagi mengenai perilaku bertanggung jawab siswa dalam menjaga kebersihan disekolah akan dijelaskan bahwa : (1) Partisipasi responden dilihat dari indikator empati terhadap lingkungan memiliki rata-rata persentase yang baik yaitu terdapat sekitar $12 \%$ responden yang sangat setuju dan 56\% $68 \%$ responden yang menjawab setuju dalam indikator ini. Hal itu menandakan bahwa perilaku empati terhadap lingkungan mereka terhadap apa itu sampah secara umum sudah baik. (2) Partisipasi responden dilihat dari indikator pengidentifikasian isu lingkungan memiliki rata-rata persentase yang baik yaitu terdapat $8 \%-32 \%$ responden yang menjawab sangat setuju dan 48\% - 64\% responden yang menjawab setuju dalam indikator ini. Hal itu menandakan bahwa partisipasi responden terhadap perilaku pengidentifikasian isu lingkungan secara umum sudah baik. (3) Partisipasi responden dilihat dari indikator kesadaran untuk menjaga kualitas lingkungan memiliki rata- 
rata persentase yang baik yaitu terdapat $12 \%$ - 32\% responden yang menjawab sangat setuju dan $40 \%$ - 56\% responden yang menjawab setuju dalam indikator ini. Hal itu menandakan bahwa partisipasi responden terhadap perilaku kesadaran untuk menjaga kualitas lingkungan secara umum sudah baik. (4) Partisipasi responden dilihat dari indikator keterlibatan dalam mencapai hasil yang diinginkan memiliki rata-rata persentase yang baik yaitu terdapat $12 \%$ - 44\% responden yang menjawab sangat setuju dan $40 \%$ - 64\% responden yang menjawab setuju dalam indikator ini. Hal itu menandakan bahwa perilaku mereka terhadap keterlibatan dalam mencapai hasil yang diinginkan secara umum sudah baik.

\section{PENUTUP}

Hasil analisis korelasi tidak diperoleh hubungan yang signifikan antara pengetahuan pengelolaan sampah dengan perilaku bertanggung jawab siswa dalam menjaga kebersihan di sekolah, hal ini menunjukan bahwa tidak terjadi hubungan yang cukup kuat antara pengetahuan pengelolaan sampah dan perilaku bertanggung jawab. Berdasarkan hasil perhitungan koefisien determinasi didapatkan nilai 50\%. Nilai tersebut menunjukan bahwa persentase hubungan antara pengeruh variable bebas (pengetahuan pengelolaan sampah) terhadap variable terikat (perilaku bertanggung jawab) sebesar $50 \%$. Artinya tidak semua responden memiliki pengetahuan tinggi juga pasti memiliki perilaku bertanggung jawab yang tinggi juga. Hasil penelitian juga memberikan implikasi bahwa sebenarnya responden yaitu siswa peserta ekskul KIR di SMAN 34 Jakarta sudah memiliki pengetahuan pengelolaan sampah pada siswa SMAN 34 Jakarta tergolong sedang. Sedangkan perilaku bertanggung jawab pada siswa SMAN 34 Jakarta sudah tergolong baik.. Namun kedua variable ini tidak memiliki hubungan signifikan yang tinggi.

\section{DAFTAR PUSTAKA}

Agus Supriyono. 2009. Cooperative Learning Teori dan Aplikasi Paikem, Yogyakarta: Pustaka Pelajar.

Alan Blanchard. 2004. What is Contextual Learning and Teaching. Dalam http//www.Besteducationalservic e.com/contextual.pdf, 2001 
Anderson, Lorin dan Krathwohl, David. 2001 Kerangka Landasan Untuk Pembelajaran Pengajaran dan Asesmen. Diterjemahkan oleh Agung Prihantoro. Yogyakarta: Pustaka Belajar.

Badan Pengelolaan Lingkungan Hidup DKI Jakarta 2005. Status Lingkungan Hidup Daerah Provinsi DKI Jakarta. Jakarta

Benjamin S. Bloom. 1956. Taxonomy of Objectives. New York: David McKay.

1986. Mastery

Learning, New York, Kolt, Rinehart and Winston.Inc.

Bimo Walgito. 2003. Psikologi Sosial: Suatu Pengantar. Cet. ke3.Yogyakarta: Andi Offset.

Dimyati dan Mudjiono. 2006. Belajar dan Pembelajaran. Cet. ke-3. Jakarta: Rineka Cipta.

Dunlap, et,al. 2000. Measuring Endorsement of the New Ecological Paradigm. Journal of Social Issues.

Eddy, Karden Sontang Manik.2009. Pengelolaan Lingkungan Hidup. Jakarta: Djambatan, Cet. Ketiga.
Garrod, B. dan Wilson J. 2001. Aspects of Tourism: Marine Ecotourism Issues and Experiences. Channel View Publications.

Hadiwiyoto, Soewedo.

1983

Penanganan dan Pemanfaatan Sampah. Jakarta: Yayasan Idayu.

Harwantyoko dan Neltjee F. Kaatuk. 1996. MKDU Ilmu Sosial Dasar. Jakarta: Gunadarma.

Jujun Suriasumantri. 1980. Ilmu Dalam Perspektif: Sebuah Kumpulan Karangan Tentang Hakekat Ilmu. (Cetakan Kedua). Jakarta: Yayasan Obor Indonesia dan LEKNAS - LIPI.

Mark K. Smith. 2004. The Cognitive Orientation to Learning. dalam http//www. infed. org/biblio/learning_cognitive. htm, Juli, 1996.

Mergel. 2004. Instructional Design and Learning Theory. dalam http/www. usask.ca/ education/ 802papers/brenda/mergel.htm;

Mei 1998.

M. Saekhan Muchith. 2007. Pembelajaran Kontekstual, Semarang: Ra SAIL Media Group. 
Jurnal Parameter Volume 31 No. 1

DOI : doi.org/10.21009/parameter.311.05

P-ISSN : 0216-261X E-ISSN : 2620-9519

Ngalim Purwanto. 1998. Prinsip-prinsip

dan Teknik Evaluasi Pengajaran.

Jakarta: Remaja Karya.

Slamet, Juli Soemirat. 1996. Kesehatan

Lingkungan. $\quad$ Yogyakarta:

GADJAH

MADA

UNIVERSITY PRESS.

Tatang. 2012. Ilmu Pendidikan. Bandung: Pustaka Setia.

Toeti Soekamto dan Udin Saripudin Winataputra. 1997. Teori Belajar dan Model-Model Pembelajaran.

Jakarta: P2T Universitas

Terbuka.

Wanda Y. Gin.2001. Jean PiagetIntellectual Development dalam http//www.sk.com.br/ skpiaget.html

Zaini. 1991. Belajar Sebagai Sarana Pengembang Fitrah Manusia. Jakarta: Kalam Mulia. 